\title{
Molecular Detection of Phytophthora ramorum, the Causal Agent of Sudden Oak Death in California, and Two Additional Species Commonly Recovered from Diseased Plant Material
}

\author{
Frank N. Martin, Paul W. Tooley, and Cheryl Blomquist
}

First author: U.S. Department of Agriculture-Agricultural Research Service (USDA-ARS), 1636 East Alisal St., Salinas, CA 93905; second author: USDA-ARS, Foreign Disease-Weed Science Research Unit, 1301 Ditto Ave., Ft. Detrick, MD 21702; and third author: California Department of Food and Agriculture, Plant Pest Diagnostics Branch, 3294 Meadowview Rd., Sacramento 95832. Accepted for publication 10 February 2004.

\begin{abstract}
Martin, F. N., Tooley, P. W., and Blomquist, C. 2004. Molecular detection of Phytophthora ramorum, the causal agent of sudden oak death in California, and two additional species commonly recovered from diseased plant material. Phytopathology 94:621-631.

Sudden oak death is a disease currently devastating forest ecosystems in several coastal areas of California. The pathogen causing this is Phytophthora ramorum, although species such as $P$. nemorosa and $P$. pseudosyringae often are recovered from symptomatic plants as well. A molecular marker system was developed based on mitochondrial sequences of the coxI and II genes for detection of Phytophthora spp. in general, and $P$. ramorum, $P$. nemorosa, and $P$. pseudosyringae in particular. The firstround multiplex amplification contained two primer pairs, one for amplification of plant sequences to serve as an internal control to ensure that extracted DNA was of sufficient quality to allow for polymerase chain reaction (PCR) amplification and the other specific for amplification of sequences from Phytophthora spp. The plant primers amplified the desired amplicon size in the 29 plant species tested and did not interfere with amplification by the Phytophthora genus-specific primer pair. Using DNA from purified cultures, the Phytophthora genus-specific primer pair amplified a fragment diagnostic for the genus from all 45 Phytophthora spp. evaluated, although the efficiency of amplification was lower for $P$. lateralis and $P$. sojae than for the other species. The genus-specific

the resulting amplicons were smaller than the Phytophthora genus-specific amplicon. The products of the first-round amplification were diluted and amplified with primer pairs nested within the genus-specific amplicon that were specific for either $P$. ramorum, $P$. nemorosa, or $P$. pseudosyringae. These species-specific primers amplified the target sequence from all isolates of the pathogens under evaluation; for $P$. ramorum, this included 24 isolates from California, Germany, and the Netherlands. Using purified pathogen DNA, the limit of detection for P. ramorum using this marker system was $\approx 2.0 \mathrm{fg}$ of total DNA. However, when this DNA was spiked with DNA from healthy plant tissue extracted with a commercial miniprep procedure, the sensitivity of detection was reduced by 100 - to 1,000 -fold, depending on the plant species. This marker system was validated with DNA extracted from naturally infected plant samples collected from the field by comparing the sequence of the Phytophthora genus-specific amplicon, morphological identification of cultures recovered from the same lesions and, for $P$. ramorum, amplification with a previously published rDNA internal transcribed spacer species-specific primer pair. Results were compared and validated with three different brands of thermal cyclers in two different laboratories to provide information about how the described PCR assay performs under different laboratory conditions. The specificity of the Phytophthora genus-specific primers suggests that they will have utility for pathogen detection in other Phytophthora pathosystems.
\end{abstract} primer pair did not amplify sequences from the 30 Pythium spp. tested or from 29 plant species, although occasional faint bands were observed for several additional plant species. With the exception of one plant species,
Additional keyword: mitochondrial DNA.
Phytophthora ramorum (Werres, de Cock and Man in 't Veld) causes sudden oak death (SOD), a disease which has killed thousands of oak trees along the California coast $(16,35)$ and also has been detected in southern Oregon (18). This pathogen was first described in Europe causing twig blight on Rhododendron and Viburnum spp. (40) before being identified as the pathogen species responsible for widespread death of oaks in California (35). The disease currently has spread to 12 counties in the state and has a broad host range of at least 11 plant families and 28 plant

\section{Corresponding author: F. N. Martin; E-mail address: fmartin@pw.ars.usda.gov}

* The $\boldsymbol{e}$-Xtra logo stands for "electronic extra" and indicates that the online version contains supplemental material not included in the print edition. The online version includes a link to F. Martin's website where additional data is presented as well as a link to the APHIS website, which contains current information on sudden oak death and two other molecular methods for detection of the pathogen responsible for the disease in California.

\section{Publication no. P-2004-0416-01R}

This article is in the public domain and not copyrightable. It may be freely reprinted with customary crediting of the source. The American Phytopathological Society, 2004. species $(16,23,34)$. Aside from its impact on disruption of the forest ecosystem and the practical problems associated with disease management and removal of dead trees, this pathogen has had a significant regulatory impact on the state as well. Currently, there are quarantine restrictions at both the federal (38) and state level (7) affecting movement of specific plant species outside of infested counties.

In addition to $P$. ramorum, two recently described species, P. nemorosa (22) and P. pseudosyringae (25), also can be recovered from symptomatic tissue from a range of different hosts in the forest ecosystem. Both species initially were referred to as a P. ilicis-like species due to their morphological similarity prior to publication of the species description $(22,35)$. The foliar disease symptoms caused by these pathogens are indistinguishable from those caused by $P$. ramorum, and the host range and geographic distribution is similar. $P$. nemorosa commonly is recovered from leaf spots and is associated with individual lethal trunk cankers, but not with large tree stand mortality as is P. ramorum (22). Thus far, $P$. pseudosyringae has been observed primarily as a leaf and twig pathogen in California (C. Blomquist, unpublished data), which is in contrast to the description as a root and collar rot 
pathogen of trees in Europe in the original species description (25). These two additional species can be distinguished in culture from $P$. ramorum in part by the fact they are homothallic and do not produce chlamydospores $(22,25)$, whereas $P$. ramorum is heterothallic and produces chlamydospores $(40,41)$. Although morphologically similar, P. pseudosyringae can be differentiated from $P$. nemorosa by the catenulate hyphal swellings produced in water culture and by having a higher temperature growth optimum $(22,25)$.

Due to the wide host range of $P$. ramorum and its potential for spread to new areas of the United States, quarantine regulations have been developed by the U.S. Department of Agriculture Animal and Plant Health Inspection Service (USDA-APHIS) to restrict the potential spread of $P$. ramorum from known infested areas (specific counties in California and Oregon) on a variety of host species (38). To clarify the current distribution of the pathogen, field surveys have been organized in states that have potential hosts of the pathogen and environmental conditions favorable for disease development (J. Jones, personal communication). In addition, Canada has placed restrictions on importation of reported $P$. ramorum host species (8). The development of accurate and rapid diagnostic methods for $P$. ramorum will be key for providing the tools needed for detecting the pathogen and determining its potential for becoming established in new regions. Due to the presence of other Phytophthora spp. that cause similar symptoms on diseased plants, symptom expression alone will not be adequate for accurate diagnosis of this pathogen. If isolated in pure culture, $P$. ramorum can be identified by its unique morphological characteristics; however, due to morphological similarities of other the Phytophthora spp. that may be recovered from symptomatic tissue, identification of these species by morphology alone may require special training. Furthermore, successful culturing of $P$. ramorum seems dependent on environmental conditions where the samples were collected, host response, and the presence of competing organisms in the plant tissue, all of which may inhibit culturing of the pathogen $(35$; C. Blomquist, unpublished data). A strong need exists for additional tools that will allow for rapid and accurate identification of pathogens from symptomatic tissue that are independent of environmental conditions and allows for processing of large sample sizes.

Methods based on DNA sequence information hold much promise in $P$. ramorum detection; however, if used for field diagnosis, they must be able to clearly distinguish $P$. ramorum from several other Phytophthora spp. that may be encountered, including $P$. nemorosa, $P$. pseudosyringae, $P$. cinnamomi, $P$. syringae, P. hevea, $P$. cactorum, P. citricola, and others (10; C. Blomquist, unpublished data). Thus, a high research priority has been the development of a polymerase chain reaction (PCR)-based detection method for P. ramorum. PCR-based methods have proven to be among the most rapid, specific, and sensitive methods available for detection of Phytophthora spp. $(1,3,13,20,36,37,42)$. A molecular detection system already has been described for $P$. ramorum based on the internal transcribed spacer (ITS) region of the ribosomal DNA (17). In this method, one set of species-

TABLE 1. Isolates of Phytophthora spp. used in this investigation

\begin{tabular}{|c|c|c|c|c|}
\hline Species & Group $^{\mathrm{a}}$ & Isolate number ${ }^{\mathrm{b}}$ & Host & Origin \\
\hline Phytophthora boehmeriae & II & $325^{\mathrm{PT}}, \mathrm{P} 1257^{\mathrm{MC}}$ & Boehmeriae nivia & Papua New Guinea \\
\hline P. capsici & II & $\mathrm{Cp}-25^{\mathrm{DJM}}(\mathrm{A}-2)$ & Citrullus lantatus & Florida \\
\hline P. citrophthora & II & $\mathrm{Ct}-1^{\mathrm{DJM}}$ & Theobroma cacao & Brazil \\
\hline$P$. clandestine & I & IMI287317DC & Trifolium subterranean & Australia \\
\hline P. colocasiae & IV & $346^{\mathrm{PT}}, \mathrm{P} 3773^{\mathrm{MC}}$ & Colocasia esculenta & Indonesia \\
\hline P. erythroseptica & VI & $367^{\mathrm{PT}}$ & Solanum tuberosum & New York \\
\hline P. fragariae fragariae & $\mathrm{V}$ & $395^{\mathrm{PT}}$, ATCC 13974 & Fragaria $\times$ ananassa & New York \\
\hline \multirow[t]{3}{*}{$P$. gonapodyides } & VI & $393^{\mathrm{PT}}, \mathrm{NY} 353^{\mathrm{WW}}$ & Malus sylvestris & New York \\
\hline & $\ldots$ & $\mathrm{P} 245^{\mathrm{DC}}, \mathrm{IMI} 389725$ & Salix mastsudana & United Kingdom \\
\hline & $\ldots$ & P501 DC, IMI389729 & Ilex roots & United Kingdom \\
\hline P. heveae & II & $\mathrm{Hv}-2^{\mathrm{DJM}}$ & Theobroma cacao & Brazil \\
\hline P. hibernalis & IV & $337^{\mathrm{PT}}$, ATCC $32995, \mathrm{P} 0647^{\mathrm{MC}}$ & Citrus sinensus & California \\
\hline P. iranica & I & IMI158964 DC & S. melongera & Iran \\
\hline P. katsurae & II & IMI360596 $\mathrm{DC}$ & Cocos nucifera & Ivory Coast \\
\hline P. lateralis & $\mathrm{V}$ & IMI040503 (Type) & Chamaecyparis & United States \\
\hline P. medii & II & IMI129185 DC & Hevea brasiliensis & India \\
\hline P. megasperma & $\mathrm{V}$ & IMI133317 & M. sylvestris & Australia \\
\hline P. megakarya & II & $328^{\mathrm{PT}}, \mathrm{P} 184^{\mathrm{CB}}$ & T. cacao & Cameroon \\
\hline P. melonis & VI & IMI325917 DC & Cuсumis sp. & China \\
\hline P. mirabilis & IV & $340^{\mathrm{PT}}$, ATCC $64070, \mathrm{P} 3007^{\mathrm{MC}}$ & Mirabilis jalapa & Mexico \\
\hline \multirow[t]{2}{*}{ P. nemorosa } & IV & $\mathrm{P}-13^{\mathrm{EH}}, 482^{\mathrm{PT}}$ Type & Lithocarpus densiflorus & California \\
\hline & 2 & $2052.1^{\mathrm{EH}}, 483^{\mathrm{PT}}$ & L. densiflorus & Oregon \\
\hline P. nicotianae & II & $331^{\mathrm{PT}}$ & Nicotiana tabacum & North Carolina \\
\hline & II & $\mathrm{Pl}-5^{\mathrm{DJM}}, \mathrm{P} 626^{\mathrm{UCR}}$ & T. cacao & Brazil \\
\hline \multirow{2}{*}{ P. phaseoli } & $\mathrm{V}$ & $352^{\mathrm{PT}}$, АTCC 60171, CBS 556.88 & Phaseolus lunatus & Unknown \\
\hline & $\ldots$ & $373^{\mathrm{PT}}$ & P. lunatus & Delaware \\
\hline
\end{tabular}

${ }^{a}$ Waterhouse morphological group (Waterhouse 1963).

${ }^{\mathrm{b}} \mathrm{CB}=$ Clive Brasier, DC = DNA supplied by David Cooke, $\mathrm{MC}=$ Michael Coffey, $\mathrm{KD}=$ Ken Deahl, PH = Phil Hamm (E. Hansen), DJM = Dave Mitchell, DS = Dave Shaw, PT = Paul Tooley, UCR = University of California at Riverside, SW = Sabine Werres, WW = Wayne Wilcox, DR = Dave Rizzo, CDFA = Cheryl Blomquist, California Department of Food and Agriculture, and GB = Greg Browne.

${ }^{\mathrm{c}}$ Species groupings of Brasier et al. (5). 
specific PCR primers was designed to amplify a 687-bp fragment from the ITS1, 5.8S, and ITS2 regions of $P$. ramorum, while a second nonspecific pair amplifies a 291-bp portion of the ITS2 region nested within the first amplicon. This method has been used for preliminary identification of new hosts of $P$. ramorum $(16,17,35)$; the first set of primers has been used as a single-round amplification procedure in at least one European laboratory (27) and is one of the procedures selected by USDA-APHIS for conducting the pathogen survey in a number of states in 2003 (28). Another molecular detection system designed to identify and detect $P$. lateralis (42) also has been modified for use in detecting $P$. ramorum (28) and a detection system based on sequence variation of the $\beta$-tubulin gene is under development (2).

One complicating factor in diagnosis of foliar pathogens from forest ecosystems and nursery settings is that there are several Phytophthora spp. that can cause symptoms similar to those caused by $P$. ramorum. Although it is important to accurately identify $P$. ramorum in field samples, from a diagnostician's stand point it also would be helpful to know if other Phytophthora spp. are responsible for the observed disease symptoms. This would not only assist in development of disease management strategies but also help clarify the disease problems of the various hosts under study, including the possible identification of new pathogens. Furthermore, with any molecular diagnostic system it also is important to have an internal control to validate that the DNA extraction procedure produced template DNA of sufficient quality to allow DNA amplification to take place, thereby reducing the potential for false negatives (42).

The objective of this study was to develop a mitochondrially based PCR molecular marker system that was specific for Phytophthora spp. and could be used to detect a range of species. The mitochondrial genome was chosen for a target due to its high copy number and identification of a specific region of sequence heterogeneity among species that was bordered by highly conserved sequences. The Phytophthora genus-specific primer pair was developed from conserved sequences in the $3^{\prime}$ end of the coxII gene and the $5^{\prime}$ end of the coxI gene and amplified the spacer region between these two genes. Sequence variation was observed in the spacer region that allowed for the development of nested species-specific primer pairs for identification of $P$. ramorum, $P$. nemorosa, or $P$. pseudosyringae. To facilitate the use of this marker system for processing field samples, a primer pair for amplification of plant sequences was developed to use in the firstround amplification to serve as a positive control to ensure the quality of DNA extraction.

\section{MATERIALS AND METHODS}

Cultures and DNA extraction. Cultures of Phytophthora spp. used in this study are listed in Table 1 and have been described previously $(32,33)$. Cultures were grown on Rye A medium (9) at $20^{\circ} \mathrm{C}$ in darkness and genomic DNA was extracted by the method

TABLE 1. (Continued from preceding page)

\begin{tabular}{|c|c|c|c|c|}
\hline Species & Group $^{a}$ & Isolate number ${ }^{b}$ & Host & Origin \\
\hline \multirow[t]{2}{*}{ P. phaseoli } & $\ldots$ & $403^{\mathrm{PT}}$ & P. lunatus & Delaware \\
\hline & $\ldots$ & $406^{\mathrm{PT}}$ (Race D) & P. lunatus & Maryland \\
\hline P. porri & III & CBS 782.97DC & Brassica chinensis & The Netherlands \\
\hline P. primulae & III & CBS $620.97^{\mathrm{DC}}$ & Primula acaulis & Germany \\
\hline \multirow[t]{6}{*}{ P. pseudosyringae } & IV & PSEU16 ${ }^{\mathrm{TJ}}, 484^{\mathrm{PT}}$, NFV-BU97-15 & Fagus sylvatica & Germany \\
\hline & $\ldots$ & $\mathrm{P} 96^{\mathrm{EH}}, 485^{\mathrm{PT}}$ & Umbellularia californica & Contra Costa Co., CA \\
\hline & $\ldots$ & $470^{\mathrm{PT}}, \mathrm{P} 193907 \mathrm{~A}^{\mathrm{CDFA}}$ & Manzanita sp. & Royal Oaks, CA \\
\hline & $\ldots$ & $471^{\mathrm{PT}}, 1168699^{\mathrm{CDFA}}$ & $U$. californica & Napa, CA \\
\hline & $\ldots$ & $472^{\mathrm{PT}}, 1168676^{\mathrm{CDFA}}$ & U. californica & Calistoga, CA \\
\hline & $\ldots$ & $473^{\mathrm{PT}}, \mathrm{P} 110361^{\mathrm{CDFA}}$ & U. californica & Yountville, CA \\
\hline P. pseudotsugae & I & $308^{\mathrm{PT}}, \mathrm{H} 270^{\mathrm{PH}}$ & Pseudotsugae menziesii & Oregon \\
\hline$P$. quercina & $\mathrm{V}$ & IMI340618 & Quercus robur & Germany \\
\hline \multirow[t]{24}{*}{$P$. ramorum } & IV & Prn-1, PD93/844 ${ }^{\text {SW }}$ & Rhododendron sp. & The Netherlands \\
\hline & $\ldots$ & Prn-2, PD $94 / 844^{\mathrm{SW}}$ & Rhododendron sp. & The Netherlands \\
\hline & $\ldots$ & Prn-3, PD $98 / 8 / 6743^{\text {SW }}$ & Rhododendron sp. & The Netherlands \\
\hline & $\ldots$ & Prn-4, PD98/8/6285 & Rhododendron sp. & The Netherlands \\
\hline & $\ldots$ & Prn-5, PD98/8/2627 ${ }^{\text {SW }}$ & Rhododendron sp. & The Netherlands \\
\hline & $\ldots$ & Prn-6, PD98/8/5233sw & Viburnum sp. & The Netherlands \\
\hline & $\ldots$ & Prg-1, BBA $69082^{\text {SW }}$ & Rhododendron sp. & Germany \\
\hline & $\ldots$ & Prg-2, BBA 9/95 ${ }^{\text {SW }}$, CBS 101553 (Type) & Rhododendron catawbiense & Germany \\
\hline & $\ldots$ & Prg-3, BBA $14 / 98-\mathrm{a}^{\mathrm{SW}}$ & R. catawbiense & Germany \\
\hline & $\ldots$ & Prg-4, BBA $12 / 98^{\mathrm{SW}}$ & R. catawbiense & Germany \\
\hline & $\ldots$ & Prg-5, BBA $13 / 99-1^{\text {SW }}$ & R. catawbiense & Germany \\
\hline & $\ldots$ & Prg-6, BBA $16 / 99^{\text {SW }}$ & Viburnum bodnantense & Germany \\
\hline & $\ldots$ & Prg-7, BBA 9/3 & Water & Germany \\
\hline & $\ldots$ & Prg-8, BBA $104^{\text {SW }}$ & Water & Germany \\
\hline & $\ldots$ & $288^{\mathrm{MG}}$ & Rhododendron sp. & California \\
\hline & $\ldots$ & $73101^{\mathrm{CDFA}}$ & L. densiflorus & California \\
\hline & $\ldots$ & $044519^{\mathrm{CDFA}}$ & U. californica & California \\
\hline & $\ldots$ & $044522^{\mathrm{CDFA}}$ & L. densiflorus & California \\
\hline & $\ldots$ & P072648 CDFA & Q. agrifolia & California \\
\hline & $\ldots$ & $201 C^{D R}$ & Rhododendron sp. & California \\
\hline & $\ldots$ & $0217^{\mathrm{DR}}$ & Rhododendron sp. & California \\
\hline & $\ldots$ & Coen $^{\mathrm{MG}}$ & Rhododendron sp. & California \\
\hline & $\ldots$ & $013^{\mathrm{DR}}$ & L. densiflorus & California \\
\hline & $\ldots$ & $016^{\mathrm{DR}}$ & Q. agrifolia & California \\
\hline P. richardiae & VI & ATCC $46538^{\mathrm{DC}}$ & Zantedeschia sp. root & The Netherlands \\
\hline P. sojae & $\mathrm{V}$ & $312^{\mathrm{PT}}$, ATCC 48068 & Glycine $\max$ & Wisconsin \\
\hline P. syringae & III & IMI296829 & Rubus idaeus & Scotland \\
\hline P. tentaculata & I & CBS $552.96^{\mathrm{DC}}$ & Chrysanthemum leucanth. & Germany \\
\hline Phytophthora sp. "O" group & $\ldots$ & P246 ${ }^{\mathrm{DC}}, \mathrm{IMI} 389751$ & Salix roots & United Kingdom \\
\hline P. taxon Pgchlamydo ${ }^{c}$ & $\ldots$ & P510 DC, IMI389731 & Pseudotsugae roots & Canada \\
\hline P. taxon Raspberry ${ }^{c}$ & $\ldots$ & P896 ${ }^{\mathrm{DC}}, \mathrm{IMI} 389744$ & Soil & Tasmania \\
\hline
\end{tabular}


of Goodwin et al. (19) or a boiling miniprep procedure (31). Cultures of Pythium spp. were from the culture collection of F. Martin with classifications based on the keys of Van der PlaatsNiterink (39) and DNA extraction done by a miniprep procedure (30). Plant DNA was extracted using a miniprep procedure developed for Pythium spp. (30) or using lyophilized tissue ground with liquid nitrogen and extracted with a FastPrep DNA extraction kit from Qbiogene (Carlsbad, CA). DNA concentrations were determined spectrophotometrically or by quantitation on agarose gels stained with ethidium bromide in comparison with commercially obtained standards. Extracted DNA for 19 of the cultures examined was kindly provided by D. Cooke (Table 1).

Samples of DNA from plant samples collected from the field exhibiting disease symptoms were processed at the California Department of Food and Agriculture (CDFA). Leaf lesions and stem cankers were plated on PARP (pimaricin, ampicillin, rifampicin, and PCNB) medium for selective isolation of Phytophthora spp. (26). Tissue samples also were removed for DNA extraction using the FastPrep extraction kit in accordance with the manufacturer's instructions and $2 \mu \mathrm{l}$ was used for PCR amplifications. The ITSbased species-specific primers of Garbelotto et al. $(17,28)$ were used to confirm the presence of $P$. ramorum.

Primers and DNA amplification. Plant primers FMPl-2b (dGCGTGGACCTGGAATGACTA) and FMPl-3b (dAGGTTGTATTAAAGTTTCGATCG) were constructed from the mitochondrially encoded cytochrome oxidase I gene (base 522 to 664 in Pisum sativum, X14409) and generated an amplicon 143 bp in length. Phytophthora genus-specific primers FMPh-8b (dAAAAGAGAAGGTGTTTTTTATGGA) and FMPh-10b (dGCAAAAGCACTAAAAATTAAATATAA) were derived from mitochondrial sequences of the coxII (base 624 to 657) and coxI gene (base 73 to 98 ), respectively, and amplified a product $457 \mathrm{bp}$ in length for Phytophthora ramorum. Sequences of the genus-specific amplicon for $P$. ramorum, $P$. nemorosa, and $P$. pseudosyringae have been deposited in GenBank (AY534689, AY534690, and AY53691, respectively). Species-specific primers for $P$. ramorum (FMPr-1a, dGTATTTAAAATCATAGGTGTAATTTG and FMPr-7, dTGGTTTTTTTAATTTATATTATCAATG), $P$. nemorosa (FMnem-1, AATAAAATTAATTTTAATATATAATTAG and FMnem-3, dTATGTTTAATATCTGTAAATAATAG), and $P$. pseudosyringae (FMPps-1, dCAGTTTCATTAGAAGATTATTTAC and FMPps-2, dAAAATTGTTTGATTTTATTAAGTATC) were nested within

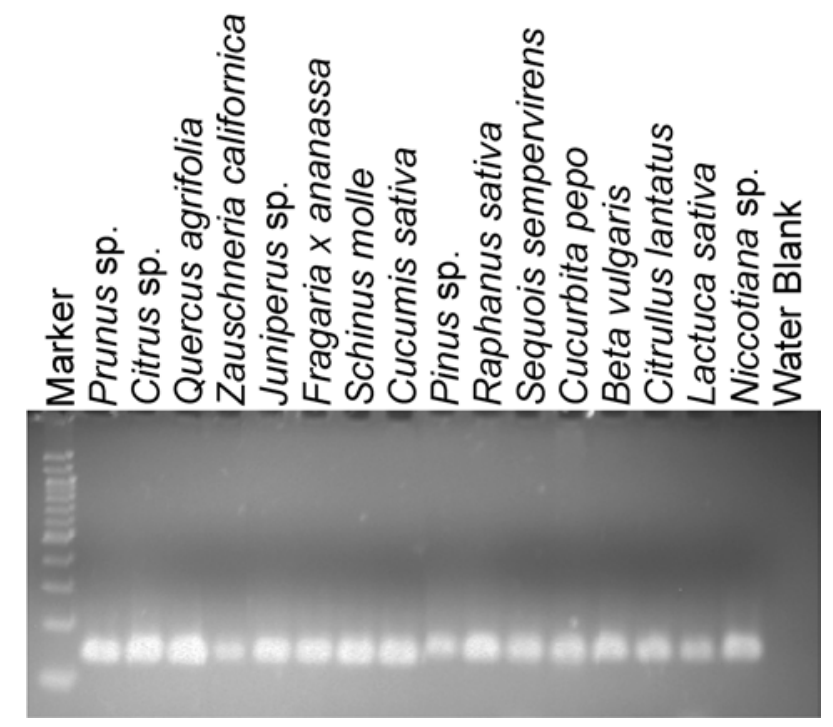

Fig. 1. Amplification of various plant species with the plant primers FMPl-2b + FMPl-3b using an annealing temperature of $66^{\circ} \mathrm{C}$ with $12 \mu \mathrm{l}$ of the amplification mixture loaded into each well of a $1.5 \%$ agarose gel. The molecular size marker is a 100-bp ladder from New England Biolabs and the size of the plant amplicon is $143 \mathrm{bp}$. the genus-specific primer pair and derived from spacer sequences between the coxII and coxI gene and generated amplicon sizes of 134, 100, and $158 \mathrm{bp}$, respectively. Primers were synthesized by Invitrogen Corporation (Carlsbad, CA). Primer pairs were tested singly in a master mix containing a final concentration of $1 \mu \mathrm{M}$ for each primer, $100 \mu \mathrm{M}$ dNTPs, $1 \times$ AmpliTaq Buffer, and 2 units of AmpliTaq (Applied Biosystems, Foster City, CA) in a total volume of $25 \mu \mathrm{l}$ with varying $\mathrm{MgCl}_{2}$ concentrations and annealing temperatures to optimize the amplification. Purified water (W4502; Sigma-Aldrich, St. Louis) was used in all primer dilutions and amplifications. Glycerol (redistilled; Roche Diagnostics, Indianapolis) was diluted to make a $50 \%$ solution and evaluated at different rates as a cosolvent to enhance primer specificity. Unless otherwise indicated, DNA concentrations used were $20 \mathrm{ng}$ for Phytophthora spp., approximately $100 \mathrm{ng}$ for Pythium spp., and an estimated minimum of $100 \mathrm{ng}$ for plant species. A water blank was included as a negative control in each round of amplifications. In California, amplification was done in an Eppendorf Mastercycler Gradient Thermal cycler (Eppendorf Scientific, Westbury, NY) in a 500- $\mu$ l Eppendorf thin-walled PCR tube with the AmpliTaq added to each prechilled amplification tube prior to placing it into a preheated block of the thermal cycler. The ramping time was set at the fastest setting $\left(3^{\circ} \mathrm{C} / \mathrm{s}\right)$. In Ft. Detrick, amplifications were done in an Applied Biosystems Model 9700 thermal cycler with a ramping time of $2.3^{\circ} \mathrm{C} / \mathrm{s}$.

Once amplification parameters for the various primer pairs were determined, multiplex amplifications were evaluated in an effort to simplify the diagnostic procedure using a mixture of purified plant DNA and $20 \mathrm{ng}$ of Phytophthora DNA (at $1 \mu \mathrm{l}$ each). The first round contained the plant primer pair FMPl-2b and FMPl-3b (0.1 $\mu \mathrm{M}$ final concentration each), the Phytophthora genus-specific primer pair FMPh-8b + FMPh-10b $(1.0 \mu \mathrm{M}$ final concentration each), $1 \times$ AmpliTaq reaction buffer, $3 \mathrm{mM} \mathrm{MgCl} 2$, $100 \mu \mathrm{M}$ dNTPs, and $2 \%$ glycerol $(1 \mu \mathrm{l}$ of a $50 \%$ solution) with 2 units of AmpliTaq added to prechilled reaction mix just prior to placing into the preheated block of the thermalcycler. Bovine serum albumin (BSA; New England Biolabs, Beverly, MA; 1:20 dilution of a $100 \mathrm{mg} / \mathrm{ml}$ stock solution) was included in the reaction mix at a rate of $1 \mu \mathrm{l}$ in some experiments to enhance the efficiency of the amplification. The amplification parameters were $95^{\circ} \mathrm{C}$ for $3 \mathrm{~min}$ followed by 40 cycles of $95^{\circ} \mathrm{C}$ for $1 \mathrm{~min}$, $66^{\circ} \mathrm{C}$ for $1 \mathrm{~min}$, and $72^{\circ} \mathrm{C}$ for $1 \mathrm{~min}$, with a final extension of $72^{\circ} \mathrm{C}$ for $5 \mathrm{~min}$. The mix $(12 \mu \mathrm{l})$ was run on either a $1.5 \%$ agarose gel or a $3 \%$ Nusieve $3: 1$ gel with $0.5 \times$ Tris-borate EDTA. The product of the first amplification was diluted 1:100 in sterile water and added to a master mix containing the Phytophthora genus-specific primer pair (FMPh- $8 \mathrm{~b}+\mathrm{FMPh}-10 \mathrm{~b}, 0.1 \mu \mathrm{M}$ final concentration each), the $P$. ramorum species-specific primer pair (FMPr-1a + FMPr-7, $1 \mu \mathrm{M}$ final concentration), 1× AmpliTaq reaction buffer, $3 \mathrm{mM} \mathrm{MgCl}$, and $100 \mu \mathrm{M}$ dNTPs. A water blank and a Phytophthora control (any Phytophthora sp. for the firstround amplification and $P$. ramorum for the second-round amplification) were included in each amplification. If the results for these control amplifications were inconsistent with expectations, the amplifications were repeated. Two units of AmpliTaq were added to the prechilled reaction mixture just prior to placing the tubes into the preheated block of the thermal cycler. The amplification parameters were $95^{\circ} \mathrm{C}$ for $3 \mathrm{~min}$ followed by 35 cycles of $95^{\circ} \mathrm{C}$ for $30 \mathrm{~s}$ and $64^{\circ} \mathrm{C}$ for $30 \mathrm{~s}$, with a final extension of $72^{\circ} \mathrm{C}$ for $5 \mathrm{~min}$. Amplification of plant samples collected from the field followed this procedure with the exception that $2 \mu$ of the FastPrep DNA extraction was used in the first multiplex amplification and this was diluted 1:25 prior to addition of $1 \mu$ to the second-round multiplex amplification.

In samples from the second round of multiplex amplifications where the Phytophthora genus-specific band was amplified but the $P$. ramorum-specific amplicon was not, a second amplification of the 1:25 dilution of the first multiplex reaction was done with 
the $P$. nemorosa or $P$. pseudosyringae primer pair. The master mix was the same as the previously described second-round multiplex amplification with the exception that the only primers present were specific for P. nemorosa (FMnem-1 and FMnem-3) or P. pseudosyringae (FMPps-1 and FMPps-2) at a final concentration of $1.0 \mu \mathrm{M}$ each. The amplification cycling parameters were the same as well, except that the annealing temperature was 61 or $65^{\circ} \mathrm{C}$, respectively.

The sensitivity of the detection system was evaluated by using a dilution series of purified DNA from $P$. ramorum that had been spectrophotometrically quantified for amplification with the genus-specific primer pair. This was diluted 1:25 and $1 \mu \mathrm{l}$ was added to a second-round amplification with the nested $P$. ramorum species-specific primer pair. To evaluate the influence of plant DNA extracted with the FastPrep procedure by the CDFA noted above on the sensitivity of detection, parallel samples of the $P$. ramorum dilution series were spiked with $2 \mu$ of DNA from healthy plants prior to amplification with the genus-specific primer pair.

In an effort to identify species that were amplified from infected plant material using the Phytophthora genus-specific primer pair, templates were sequenced by the DNA Sequencing Laboratory of the Interdisciplinary Center for Biotechnological Research of the University of Florida, Gainesville using ABI 373a automated sequencers (Applied Biosystems, Foster City, CA). Templates were prepared as previously described (32) and sequenced in both directions, with the same primers used for amplification.

\section{RESULTS}

Amplification with plant primers. The plant primers amplified target sequences well with 2 to $4 \mathrm{mM} \mathrm{MgCl}_{2}$ (less amplification at $1 \mathrm{mM}$ ) with an optimum of $2 \mathrm{mM}$ (data not shown). Annealing temperatures as high as $68^{\circ} \mathrm{C}$ did not inhibit amplification. The plant primers amplified all plant species tested, including the 16 presented in Figure 1 as well as a Rhododendron sp., Aesculus californica, Salal sp., Acer macrophyllum, Arbutus menziesii, Umbellularia californica, Sambucus sp., Pseudotsuga menziesii, Rhamnus sp., Manzanita sp., Heteromeles arbutifolia, and a Liriope sp. (data not shown).

Amplification with Phytophthora genus-specific primers. The primers amplified target sequences most efficiently at $3 \mathrm{mM}$ $\mathrm{MgCl}_{2}$, with less amplification at $4 \mathrm{mM}$ and no amplification at 1 or $2 \mathrm{mM}$ (data not shown). At the stringency tested $\left(66^{\circ} \mathrm{C}\right.$ annealing temperature and the addition of glycerol at a $2 \%$ final concentration), this primer pair amplified all Phytophthora spp. tested in Figure 2 with weak amplification of Phytophthora lateralis and $P$. sojae. Additional species listed in Table 1 but not included in Figure 2 were amplified as well (data not shown) to

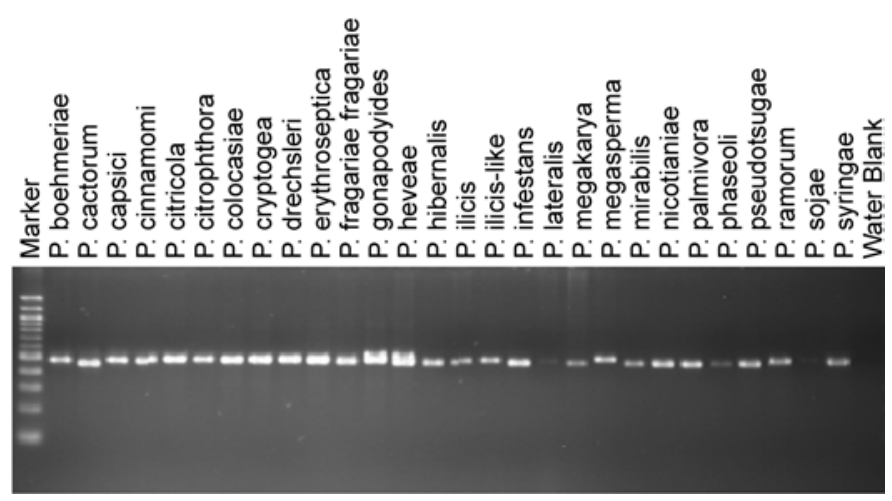

Fig. 2. Amplification of various Phytophthora spp. with the Phytophthora genus-specific primers FMPh- $8 \mathrm{~b}+\mathrm{FMPh}-10 \mathrm{~b}$ with $2 \%$ glycerol in the reaction mixture and an annealing temperature of $66^{\circ} \mathrm{C}$ with $11 \mu \mathrm{l}$ of the amplification mixture loaded into each well of a 3\% NuSieve 3:1 agarose gel. The molecular size marker is a 100-bp ladder from New England Biolabs. give a total of 45 species that have been tested. Both $P$. lateralis and $P$. sojae were amplified more efficiently if the stringency was reduced by eliminating the glycerol from the reaction mix or lowering the annealing temperature (data not shown). Depending on the amplification, doublet bands nearly the same size were occasionally observed, but these behaved the same as single bands in subsequent analysis (data not shown). None of the Pythium spp. tested was amplified with this primer pair (Fig. 3) although, in some amplifications, an occasional faint band of $\approx 0.4 \mathrm{~kb}$ was amplified for the Pythium sylvaticum isolate tested (data not shown). Under the amplification conditions used, none of the 29 plant species noted above were amplified by this primer pair (data not shown), although occasional inconsistent amplification of a band was occasionally observed with DNA from Rhododendron spp. Eliminating glycerol from the amplification mixture reduced the stringency and allowed amplification of Prunus sp., Citrus sp., Quercus agrifolia, Juniperus sp., and Fragaria $\times$ ananassa (data not shown). All isolates of Phytophthora ramorum, $P$. nemorosa, and $P$. pseudosyringae listed in Table 1 were amplified with this primer pair (data not shown).

Specificity of $P$. ramorum-, $P$. nemorosa-, and $P$. pseudosyringae-specific primers. The $P$. ramorum species-specific primer pair amplified target sequences most efficiently with a $64^{\circ} \mathrm{C}$ annealing temp and 2, 3, or $4 \mathrm{mM} \mathrm{MgCl}$, with less amplification at $1 \mathrm{mM} \mathrm{MgCl}{ }_{2}$ (data not shown). When the genus-specific fragment generated by amplification with FMPh-8b + FMPh-10b was used as a template, only P. ramorum was amplified (Fig. 4A). This species-specific primer pair amplified all $P$. ramorum isolates tested (including the type culture CBS101553, Fig. 4B), as well as isolates 201C and P072648, but did not amplify P. nemorosa (data not shown). The $P$. nemorosa primer pair amplified target sequences most efficiently with a $61^{\circ} \mathrm{C}$ annealing temperature and $4 \mathrm{mM} \mathrm{MgCl} 2$; no amplification was observed with lower concentrations of $\mathrm{MgCl}_{2}$ (data not shown). When the genus-specific fragment generated by amplification with FMPh-8b + FMPh-10b was used as a template, only P. nemorosa was amplified (Fig. 5). This species-specific primer pair amplified both $P$. nemorosa isolates listed in Table 1, including the type culture PE-13. The P. pseudosyringae-specific primer pair amplified target sequences most efficiently with a $65^{\circ} \mathrm{C}$ annealing temperature and 1 to $4 \mathrm{mM}$ $\mathrm{MgCl}_{2}$, with $3 \mathrm{mM} \mathrm{MgCl}$ subsequently used for assays (data not shown). When the genus-specific fragment generated by amplification with FMPh-8b + FMPh-10b was used as a template, only $P$. pseudosyringae isolates were amplified (Fig. 6). This primer

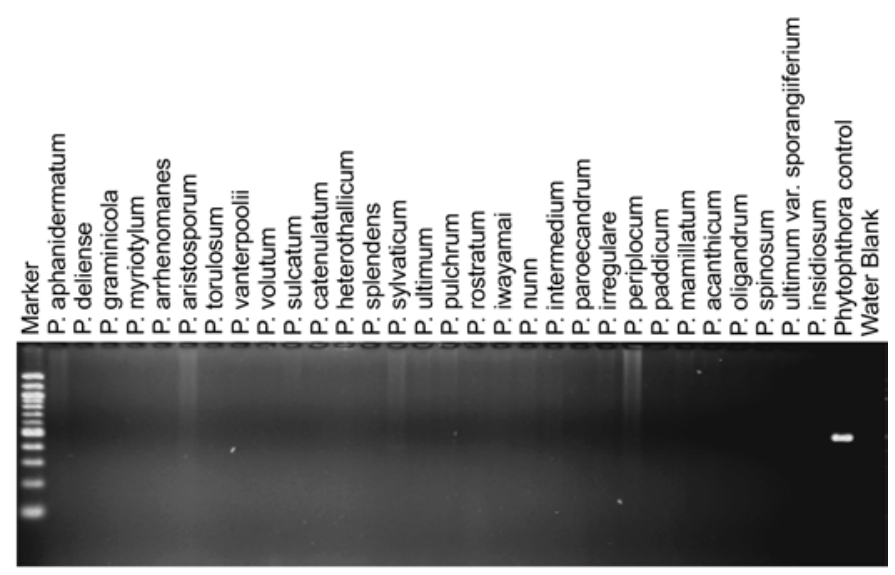

Fig. 3. Test of amplification of various Pythium spp. with the Phytophthora genus-specific primers FMPh- $8 \mathrm{~b}+\mathrm{FMPh}-10 \mathrm{~b}$ with $2 \%$ glycerol added to the reaction mixture and an annealing temperature of $66^{\circ} \mathrm{C}$. A minimum of $100 \mathrm{ng}$ of Pythium total DNA was added to each reaction with $12 \mu \mathrm{l}$ of the amplification mixture loaded into each well of a $3 \%$ NuSieve 3:1 agarose gel. The molecular size marker is a 100-bp ladder from New England Biolabs. 
pair amplified the six P. pseudosyringae isolates listed in Table 1, including isolate PSEU16, which was one of the cultures included in the species description (25), but did not amplify P. nemorosa (data not shown). In addition to the Phytophthora spp. presented in Figures 4 through 6 , the three sets of species-specific primers did not amplify bands when FMPh-8b + FMPh-10b amplicons from the following species were used as a template DNA: P. clandestine, P. humicola, P. ideai, P. iranica, P. katsurae, P. medii, P. melonis, $P$. inflata, P. primulae, $P$. richardiae, $P$. porri, $P$. quercina, $P$. tentaculata, or isolates from three of the tentative species groupings described by Brasier et al. (5) (P. taxon Raspberry, P. taxon Pgchlamydo, or Phytophthora sp. "O" group) (data not shown).

Limit of detection. A faint genus-specific band was observed with total DNA concentrations of $0.2 \mathrm{pg}$ for isolate Prg-2 of $P$. ramorum, below which no amplified products were observed (Fig. 7A). When this was diluted 1:25 and $1 \mu \mathrm{l}$ was used as target DNA for amplification with the $P$. ramorum-specific primer pair, the limit of detection was $2.0 \mathrm{fg}$. Similar results were obtained for two other isolates, with the exception that one of the isolates had an amplified species-specific band at 20.0 but not $2.0 \mathrm{fg}$ (data not shown). Spiking the DNA dilution series with $2 \mu \mathrm{l}$ of plant DNA

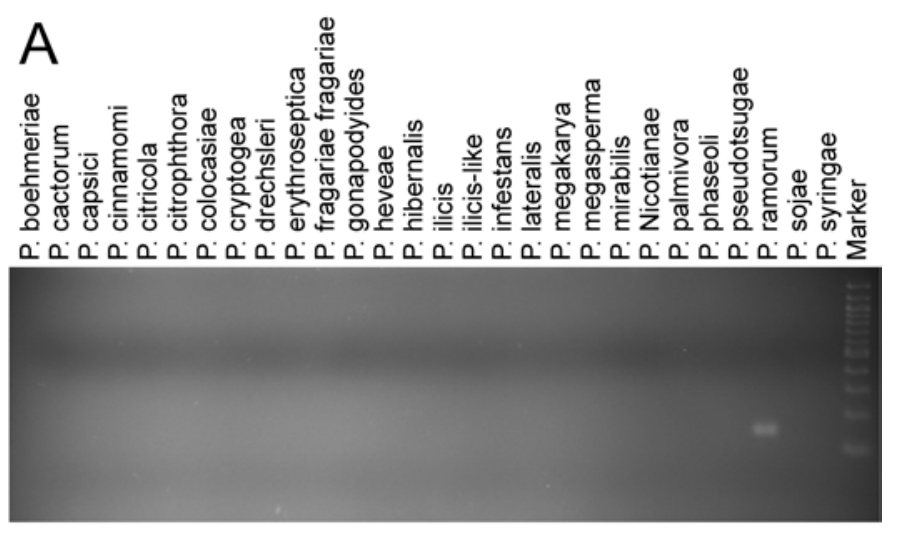

B

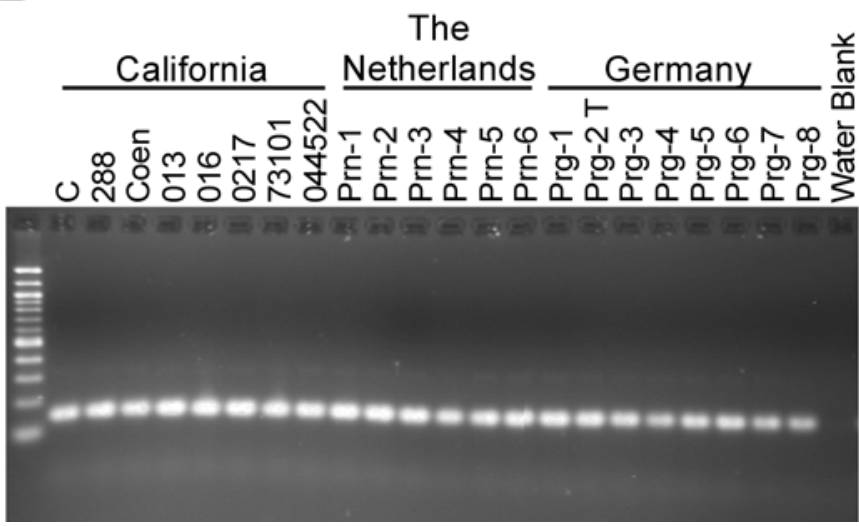

Fig. 4. A, Test for species specificity of amplification with the Phytophthora ramorum species-specific primer pair (FMPr-1a + FMPr-7) with a 1:100 dilution of the first-round amplification with the Phytophthora genus-specific primers FMPh- $8 \mathrm{~b}+$ FMPh-10b observed in Figure 2 as the target DNA. The annealing temperature was $64^{\circ} \mathrm{C}$. B, Amplification of different isolates of $P$. ramorum from California and Europe with the P. ramorum species-specific primer pair (FMPr-1a + FMPr-7). The template DNA was a 1:100 dilution of products of the first-round amplification with the Phytophthora genusspecific primers FMPh- $8 \mathrm{~b}+\mathrm{FMPh}-10 \mathrm{~b}$ using an initial concentration of $20 \mathrm{ng}$ of target DNA for each isolate. A total of $12 \mu \mathrm{l}$ of the amplification mixture was loaded into each well of a 3\% NuSieve 3:1 agarose gel. Isolate $\operatorname{Prg}-2 \mathrm{~T}$ is the type culture for this species. The molecular size marker is a 100-bp ladder from New England Biolabs. extracted at the CDFA (the same rate that would be used for evaluation of field samples) reduced the level of sensitivity by different amounts depending on the plant species (Fig. 7B). For $U$. californica, the sensitivity was reduced by a factor of approximately 100 (from $2 \mathrm{fg}$ to $200 \mathrm{fg}$ ); whereas for Acer macrophylum, Arbutus menziesii, and Rhamnus californica, the sensitivity was reduced by a factor of approximately 1,000 , with less amplification observed when spiking with Acer macrophylum DNA than the other two plant species.

Multiplex amplification. Multiplex amplifications with a mixture of DNA from Citrus sp. and either P. ramorum or P. pseudosyringae were used to optimize conditions for multiplex amplification. The first-round amplification with the plant and Phytophthora genus-specific primers was found to work best with $3 \mathrm{mM}$ $\mathrm{MgCl}_{2}, 2 \%$ glycerol, and an annealing temperature of $66^{\circ} \mathrm{C}$ (data not shown). A $0.1-\mu \mathrm{M}$ final concentration for the plant primers worked best; higher concentrations were found to reduce the amplification of the Phytophthora genus-specific amplicon due to the smaller size of the plant amplicon and the fact that the plant DNA concentration was much higher than the Phytophthora DNA. The second-round multiplex amplification worked best with an annealing temperature of $64^{\circ} \mathrm{C}$ for $P$. ramorum; addition of glycerol at any concentration inhibited amplification with this primer pair. Addition of the Phytophthora genus-specific primer pair at a concentration of $0.1 \mu \mathrm{M}$ to this second round amplifica-

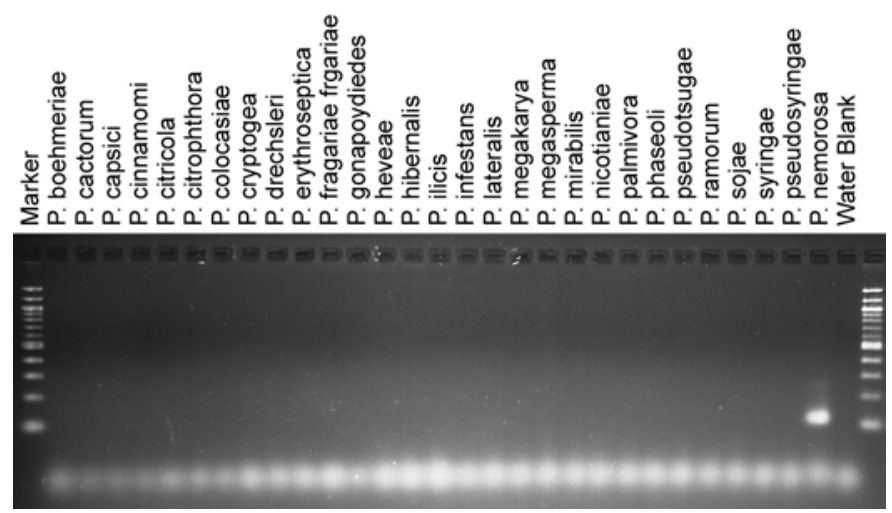

Fig. 5. Test for species specificity of amplification with the Phytophthora nemorosa species-specific primer pair (FMnem-1 + FMnem-2) with a 1:100 dilution of products of amplification with the Phytophthora genus-specific primers FMPh- $8 \mathrm{~b}+$ FMPh-10b observed in Figure 2 as the target DNA and an annealing temperature of $61^{\circ} \mathrm{C}$. A total of $12 \mu \mathrm{l}$ of the amplification mixture was loaded into each well of a 3\% NuSieve 3:1 agarose gel. The molecular size marker is a 100-bp ladder from New England Biolabs.

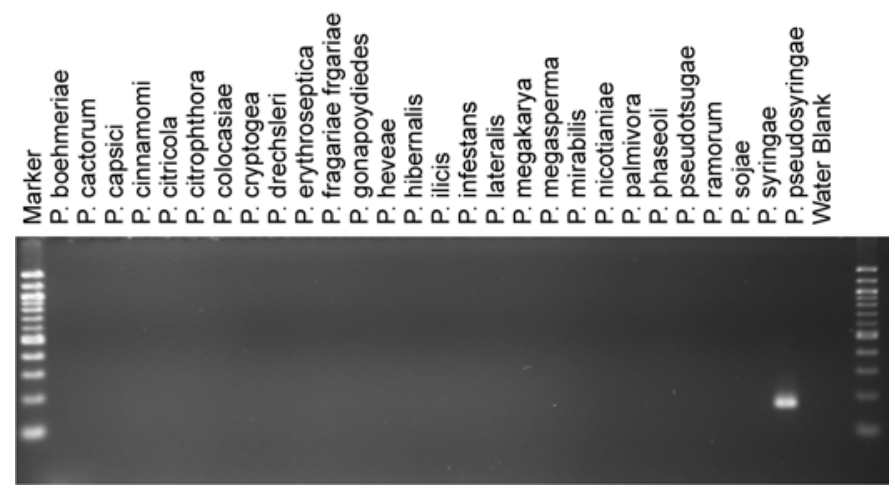

Fig. 6. Test for species specificity of amplification with the Phytophthora pseudosyringae species-specific primer pair (FMPsy-1 + FMPsy-2) with a 1:100 dilution of products of amplification with the Phytophthora genusspecific primers FMPh- 8 b + FMPh-10b observed in Figure 2 as the target DNA and an annealing temperature of $65^{\circ} \mathrm{C}$. A total of $12 \mu \mathrm{l}$ of the amplification mixture was loaded into each well of a 3\% NuSieve 3:1 agarose gel. The molecular size marker is a 100-bp ladder from New England Biolabs. 
tion enhanced the sensitivity of detection at the genus level in cases where the target Phytophthora DNA was present in low concentrations; however, higher primer concentrations reduced amplification of the $P$. ramorum diagnostic fragment (data not shown). Combining both the Phytophthora genus-specific and $P$. ramorum species-specific primers in a second round multiplex amplification produced an amplification profile that was different from using the primers individually due to generation of additional amplicons between these primer pairs that are approximately 300 bp in size (Fig. 8). Although the inclusion of BSA in the amplification master mix was found to improve the robustness of amplification, and hence the sensitivity of the assay, the use of this component of the master mix was discontinued due to formation of nonspecific background bands in some amplifications.

Amplification of field samples. Samples of extracted DNA from plant material collected from the field and processed at the
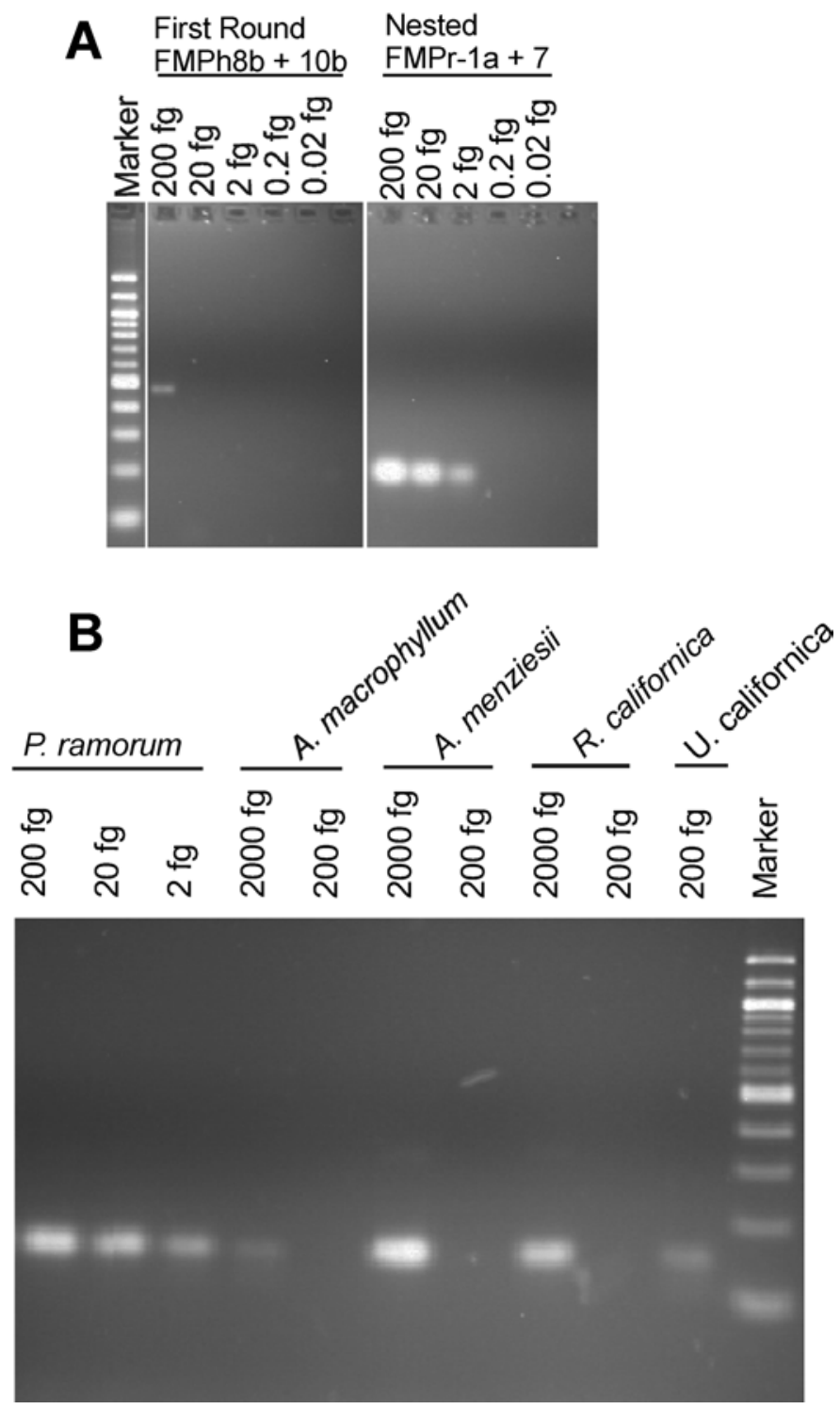

Fig. 7. Limit of detection of Phytophthora ramorum using a dilution series of total DNA. A, Amplification with the Phytophthora genus-specific primers followed by nested amplification with the $P$. ramorum species-specific primer pair using $1 \mu \mathrm{l}$ of a 1:25 dilution of the first-round amplification with the genus-specific primer pair. B, Nested amplification of purified P. ramorum DNA with the species-specific primer pair when the first-round amplification with the genus-specific primer pair was spiked with water or DNA from four different plant species. A total of $12 \mu \mathrm{l}$ of the amplification mixture was loaded into each well of a 3\% NuSieve 3:1 agarose gel. The molecular size marker is a 100-bp ladder from New England Biolabs.
CDFA were provided to F. Martin blind and assayed using the mitochondrial-based primer system described above. The plant primers were tested on a total of 84 samples, 74 of which had the appropriate-sized plant fragment amplified, indicating that the procedure used for DNA extraction provided suitable DNA for PCR analysis. Seven of the samples that were not amplified were tested to determine if this was due to the presence of PCR inhibitors by aliquoting samples into amplification mixtures with the Phytophthora genus-specific primers containing purified DNA from $P$. infestans; in all cases, the presence of the plant DNA extract inhibited amplification of the Phytophthora genus-specific fragment (data not shown). The first-round multiplex amplification with the plant primer pair and the Phytophthora genusspecific primer pair generated different-sized bands that were diagnostic of their target sequences and did not exhibit cross reactivity between primer pairs or nonspecific background amplification (Fig. 9A).

Of the 74 samples where the plant fragment was amplified, 61 samples were tested with the Phytophthora genus-specific primer pair. Of these, 32 had a Phytophthora genus-specific fragment amplified; 16 of these also had a $P$. ramorum species-specific band amplified with FMPr-1a + FMPr-7 (Table 2). The identity of four of these $P$. ramorum-positive samples was confirmed by sequencing the Phytophthora genus-specific amplicon and comparing to sequencing data for $P$. ramorum isolates Prg-2 (type culture), 013, 016, and Coen; all were identical with the exception that one isolate differed at one base (data not shown). For detection of $P$. ramorum, there was perfect agreement for these 16 samples with the analysis performed at the CDFA (culture of $P$. ramorum or positive amplification with the ITS-based marker for P. ramorum) (Table 2). The mitochondrial-based markers also identified 16 additional samples that had been infected by another Phytophthora sp., 13 of which were confirmed by pathogen recovery from infected tissue. Based on recovery from infected plant tissue and amplification with the species-specific primer pair, five of these samples were identified as a $P$. pseudosyringae. This was confirmed by sequencing the Phytophthora genus-specific amplicon for these isolates and comparing to sequencing data for the six isolates of $P$. pseudosyringae listed in Table 1; all isolates were identical with the exception of two that differed at one base (data not shown). Phytophthora isolates also were cultured from four tissue samples of $U$. californica and were amplified with $P$. nemorosa species-specific primers (Table 2); sequence analysis of the Phytophthora genus-specific amplicon for these samples confirmed they were $P$. nemorosa. Three additional positives for $P$. nemorosa were identified by species-specific amplification and sequence analysis from $U$. californica samples that

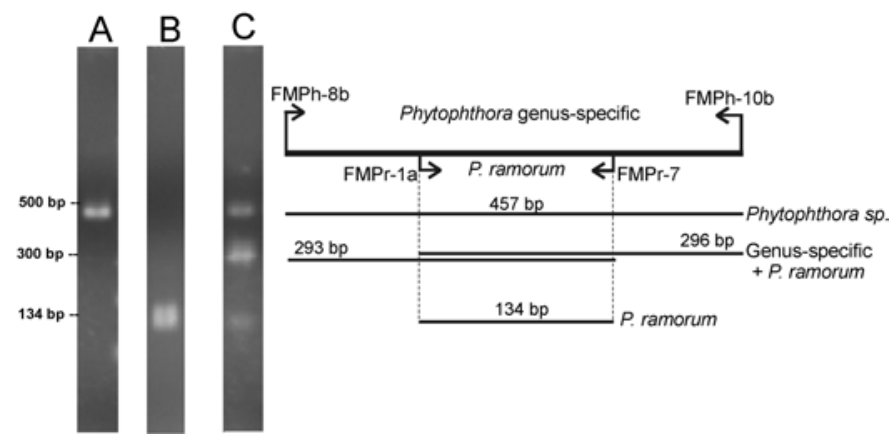

Fig. 8. Amplified products of Phytophthora ramorum using A, the Phytophthora genus-specific primer pair (FMPh-8b $+\mathrm{FMPh}-10 \mathrm{~b}), \mathbf{B}$, the $P$. ramorum species-specific primer pair (FMPr-1a + FMPr-7), and C, multiplex amplification containing $0.1 \mu \mathrm{M}$ final concentrations of the Phytophthora genusspecific primer pair (FMPhy-8b + FMPhy-10b) and $1.0 \mu \mathrm{M}$ final concentrations of the $P$. ramorum species-specific primer pair (FMPr-1a + FMPr-7). A total of $12 \mu \mathrm{l}$ of the amplification mixture was loaded into each well of a $3 \%$ NuSieve 3:1 agarose gel. 
did not yield cultures of a Phytophthora spp. when plated on a selective medium (Table 2). Sequence analysis of the Phytophthora genus-specific fragment also identified two isolates of $P$. syringae (both on Rhododendron spp.) and one unidentified Phytophthora sp. (from Rhamnus californica). One inconsistency in results between the mitochondrial marker system and pathogen isolations from infected tissue was for the Manzanita sp. sample; no Phytophthora genus-specific band was amplified but an isolate was cultured from a twig lesion (Table 2; sample 907B in Fig. 9B). Due to the small size of the lesion in this sample, different lesions were used for pathogen recovery and DNA extraction.

Depending on the sample, the first-round amplification with the Phytophthora genus-specific primer pair did not always generate a diagnostic amplicon confirming the presence of a Phytophthora sp. For example, field samples 302, 773A, and C8 had clear genus-specific bands following the first-round multiplex amplification, whereas samples 301, 303, and 322 had faint diagnostic bands (Fig. 9A). Inclusion of the Phytophthora genus-specific primer pair in the second-round amplification with the $P$. ramorum species-specific primer pair enhanced the sensitivity of detection
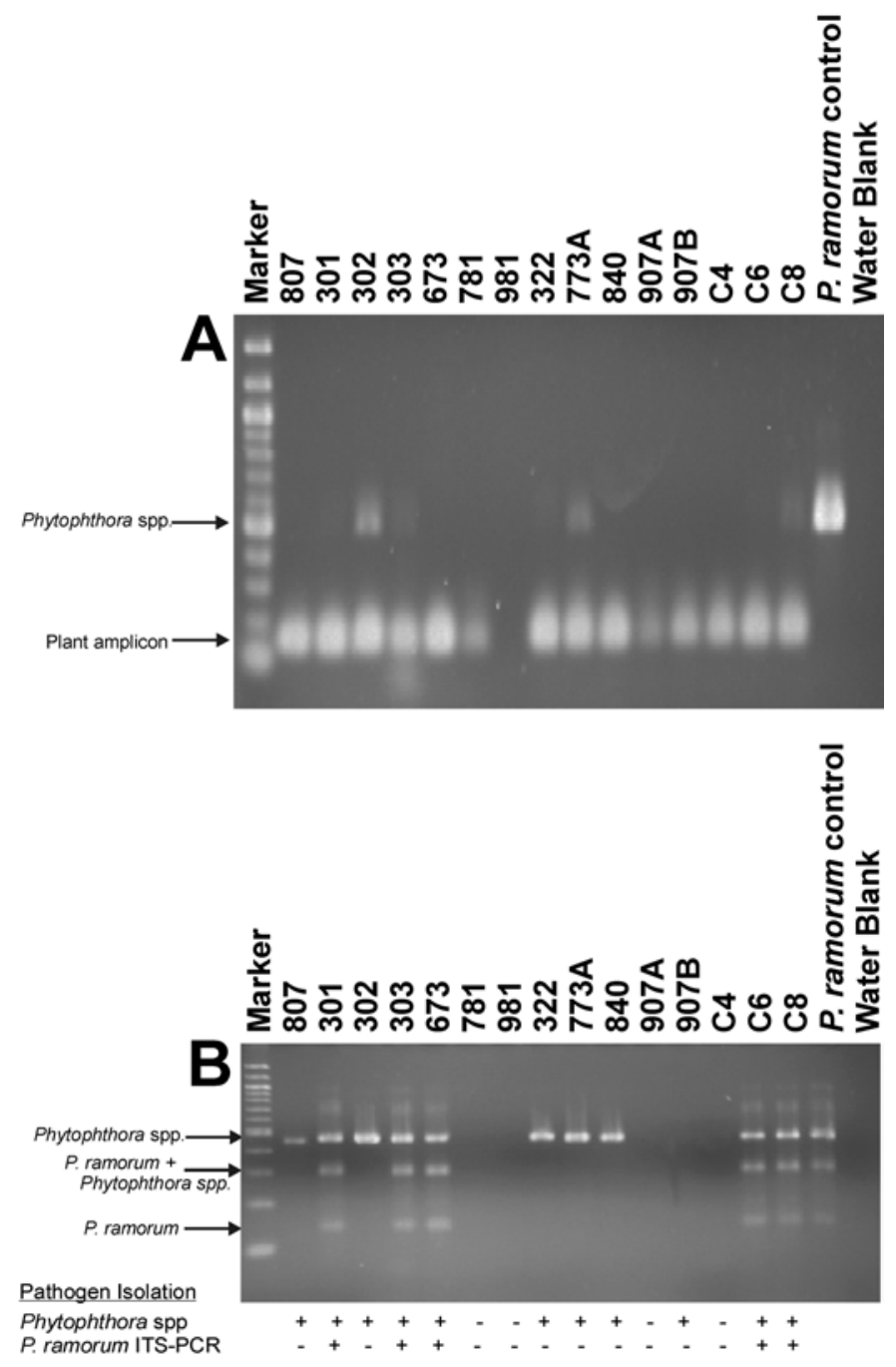

Fig. 9. A, First-round multiplex amplification of field samples with primer pairs FMPl-2b + FMPl-3b and FMPh-8b + FMPh-10b using $2 \mu$ of DNA from the FastPrep extraction. A total of $12 \mu \mathrm{l}$ of the amplification mixture was added to each well of a $1.5 \%$ agarose gel. The molecular size marker is a 100-bp ladder from New England Biolabs. B, Second-round multiplex amplification of a 1:25 dilution of the first multiplex amplification using primer pairs FMPh-8b + FMPh-10b $(0.1 \mu \mathrm{M})$ and FMPr-1a + FMPr-7 (1.0 $\mu \mathrm{M})$. A total of $12 \mu \mathrm{l}$ of the amplification mixture was loaded into each well of a $3 \%$ NuSieve 3:1 agarose gel. The molecular size marker is a 100-bp ladder from New England Biolabs. of Phytophthora sp. with visible genus-specific bands observed for a number of samples that were negative following the first round of amplification (Fig. 9B).

Amplifications with different thermalcyclers. The results discussed above were obtained in the laboratory of F. Martin using an Eppendorf Mastercycler Gradient thermal cycler. The experiments presented in Figures 2 and 4, as well as evaluation of the specificity of the genus-specific primer pair against plant DNA, were repeated in the same lab using an MJ PTC-100 (MJ Research, Waltham, MA) with the same results obtained when the annealing temperature was reduced by $1{ }^{\circ} \mathrm{C}$ for each primer pair. The experiments presented in Figures 2, 4, and 6 also were repeated at Ft. Detrick using an Applied Biosystems model 9700 thermal cycler with similar results obtained using the above-noted amplification parameters for the species-specific primer pairs (data not shown). Although the Phytophthora genus-specific primer pair did not amplify bands from Rhododendron 'Cunningham's White' or Lycopersicon esculentum with a $66^{\circ} \mathrm{C}$ annealing temperature, background bands were amplified for Kalmia latifolia 'Madeline' $(\approx 0.3 \mathrm{~kb})$, U. californica $(\approx 0.8 \mathrm{~kb})$, Glycine max $(\approx 0.4 \mathrm{~kb})$, and Solanum tuberosum $(\approx 0.3 \mathrm{~kb})$, all of which were different in size from the genus-specific diagnostic amplicon. The annealing temperature had to be increased to $67^{\circ} \mathrm{C}$ to reduce background amplification for these plant DNAs, but occasional faint bands different in size from the Phytophthora genus-specific amplicon still were observed for G. max and S. tuberosum (data not shown). At this annealing temperature, the diagnostic genusspecific band was amplified for $P$. ramorum, but not for $P$. capsici, $P$. hevae, $P$. ilicis, $P$. sojae, and some isolates of $P$. pseudosyringae (data not shown).

\section{DISCUSSION}

The described PCR-based mitochondrial DNA detection system utilized a two-step multiplex amplification procedure for determining if a Phytophthora sp. was present in symptomatic plant tissue and clarifying if it was $P$. ramorum, $P$. nemorosa, or $P$. pseudosyringae. The inclusion of a primer pair for amplification of plant sequences in the first multiplex amplification provided a positive control to confirm the quality of the DNA extract and eliminate false negatives due to the presence of PCR inhibitors or badly degraded DNA. The Phytophthora genus-specific primers amplified diagnostic amplicons from all 45 Phytophthora spp. tested and were useful in the assay for determining the presence of additional Phytophthora pathogens, such as $P$. syringae, in field samples submitted for analysis. Furthermore, using speciesspecific primers for detection of $P$. ramorum, $P$. nemorosa, and $P$. pseudosyringae nested within the genus-specific amplicon improved the sensitivity of detection in the second-round amplification. All primers exhibited a high degree of specificity in tests with purified DNA as well as field samples.

The results obtained with the mitochondrial marker system correlated well with the results obtained at the CDFA for pathogen recovery from symptomatic tissue and with PCR amplification for $P$. ramorum, using the rDNA ITS $P$. ramorum-specific primers of Garbelotto et al. (17). For $P$. ramorum, no differences in results were obtained; all samples that scored positive for $P$. ramorum in the CDFA laboratory also were positive with the mitochondrial markers. The results for four of these samples were validated by sequence analysis of the Phytophthora genus-specific amplicon and comparison with data from purified cultures of this pathogen. The mitochondrial marker system also identified 16 additional samples infected with other Phytophthora spp. that could not be identified with the ITS marker system. With a few explainable exceptions, these results correlated well with pathogen recovery in the CDFA laboratory. One exception was a sample from a Manzanita sp. where, due to the small size of the lesions, the tissue samples for DNA extraction were different from the sam- 
ples plated on selective medium; the lack of amplification of the Phytophthora genus-specific amplicon in this sample could be due to another pathogen causing the lesion that was used for DNA extraction. Another exception was amplification of a Phytophthora genus-specific amplicon in DNA extracted from symptomatic $U$. californica tissue from which a Phytophthora sp. was not cultured. Sequence analysis of the Phytophthora genus-specific amplicons confirmed that the band was not an artifact and that they were identical to $P$. nemorosa. Recovery of these pathogens from symptomatic tissue can be inconsistent, with greater success in the wetter winter and spring months and a lower frequency of recovery during the drier summer and fall months (J. Davidson, personal communication; $\mathrm{C}$. Blomquist, unpublished data). These plant samples were collected on 10 June, which may have contributed to the lack of pathogen isolation.

The Phytophthora genus-specific primer pair exhibited a high level of specificity and should be useful as a diagnostic marker for confirming the presence of a Phytophthora sp. in diseased tissue. When tested in F. Martin's laboratory with DNA from 29 plant species representing a wide taxonomic range (including reported hosts of $P$. ramorum), Rhododendron sp. was the only sample where background amplification was observed. However, this amplification was not consistent across all samples from Rhododendron sp. that were evaluated. When the primers were tested with a different thermal cycler at Ft. Detrick, amplification from Rhododendron sp. was not observed, but faint background amplifications were observed for G. $\max$ and $S$. tuberosum, although the amplicon sizes were different in size from the Phytophthora diagnostic amplicon. Likewise, the Phytophthora genus-specific primer pair exhibited a high level of specificity when evaluated against 30 Pythium spp. This may not be important for diagnosis of Phytophthora spp. associated with SOD in forest ecosystems because this is a disease of aboveground portions of the plant where Pythium spp. would rarely be encountered; however, it could be important for pathogen detection in nursery settings. The annealing temperature and concentration of glycerol are impor- tant for attaining this specificity. Reduction of annealing temperature by $1{ }^{\circ} \mathrm{C}$ or elimination of glycerol increased the nonspecific amplification of bands from some plant species, some of which were the same size as the Phytophthora diagnostic amplicon. Although the presence of these bands could compromise the use of this marker system for diagnosis of infection by a Phytophthora sp. at a genus level, they would not affect detection of $P$. ramorum, $P$. nemorosa, or $P$. pseudosyrinigae, because the species-specific primer pairs did not amplify bands in these samples (data not shown). Including the Phytophthora genus-specific primers in the second-round amplification with the species-specific primers enhanced the sensitivity of detection at the genus level, thereby increasing the accuracy of pathogen detection from field samples. However, the concentration of these primers should be lower than the species-specific primers $(0.1 \mu \mathrm{M}$ compared with $1.0 \mu \mathrm{M}$ for the species-specific primers) to prevent competition in template amplification, reducing the amount of species-specific amplification.

The effectiveness of the marker system was enhanced by using species-specific primers nested within the Phytophthora genusspecific amplicon in the second round of amplification. This provided an additional level of primer specificity to prevent nonspecific amplification from plant DNA or other organisms that might be present in infected plant material. It also improved specificity of amplification among Phytophthora spp., because occasional faint bands were observed for several species when total DNA rather than the genus-specific amplicon was used as target DNA in amplifications with the $P$. ramorum-specific primer pair (F. N. Martin, unpublished data). When the Phytophthora genusspecific amplicon was used as target DNA, the species-specific primers were highly specific and did not amplify sequences from any of the 45 other species of the genus tested. This includes the phylogenetically closely related species (33) $P$. lateralis and $P$. hibernalis for the $P$. ramorum-specific primers, as well as $P$. ilicis for the $P$. nemorosa- and $P$. pseudosyringae-specific primer pair. These species-specific primer pairs also amplified target sequences from all isolates of the pathogens evaluated (including

TABLE 2. Symptomatic plant samples collected from the field and subsamples divided for plating on selective medium for pathogen isolation or processed for DNA extraction and diagnosis with molecular markers

\begin{tabular}{|c|c|c|c|c|c|c|c|c|c|}
\hline \multirow[b]{2}{*}{ Host } & \multicolumn{3}{|c|}{ CDFA analysis $^{\mathrm{a}}$} & \multicolumn{5}{|c|}{ Mitochondrial marker system $^{\mathrm{b}}$} & \multirow[b]{2}{*}{$\begin{array}{c}\text { Sequence } \\
\text { confirmation }^{c}\end{array}$} \\
\hline & $\begin{array}{c}\text { No. of } \\
\text { samples }\end{array}$ & Pathogen & $\begin{array}{l}\text { Culture } \\
\text { isolation }\end{array}$ & $\begin{array}{l}\text { P. ramorum } \\
\text { ITS amp. }\end{array}$ & $\begin{array}{l}\text { Genus- } \\
\text { specific }\end{array}$ & $\begin{array}{l}\text { P. ramorum- } \\
\text { specific }\end{array}$ & $\begin{array}{c}\text { P. pseudo- } \\
\text { syringae-specific }\end{array}$ & $\begin{array}{l}\text { P. nemorosa- } \\
\text { specific }\end{array}$ & \\
\hline & $\ldots$ & $\ldots$ & $\ldots$ & 0 & 4 & 0 & 0 & 4 & 4-P. nemorosa \\
\hline & 6 & None & 0 & 0 & 3 & 0 & 0 & 3 & 3-P. nemorosa \\
\hline Rhododendron sp. & 6 & None & 0 & 0 & 2 & 0 & 0 & ND & 1-P. syringae \\
\hline Aesculus californica & 3 & ND & ND & 0 & 0 & 0 & ND & ND & $\ldots$ \\
\hline Acer macrophyllum & 6 & ND & ND & 0 & 0 & 0 & $1-0,5-\mathrm{ND}$ & ND & $\ldots$ \\
\hline Arbutus menziesii & 2 & ND & ND & 0 & 0 & 0 & ND & ND & $\ldots$ \\
\hline Sequoia sempervirens & 3 & None & 0 & 0 & 0 & 0 & ND & ND & $\ldots$ \\
\hline Sambucus sp. & 1 & None & 0 & 0 & 0 & 0 & ND & ND & $\ldots$ \\
\hline Salal sp. & 1 & ND & ND & 0 & 0 & 0 & ND & ND & $\ldots$ \\
\hline Pseudotsuga menziesii & 1 & ND & ND & 0 & 0 & 0 & ND & ND & $\ldots$ \\
\hline
\end{tabular}

a Plant samples from the field were processed at the California Department of Food and Agriculture (CDFA) by plating on selective medium and confirming species identification based on morphological criteria and amplification of extracted DNA with the Phytophthora ramorum-specific internal transcribed spacer) (ITS primers of Garbelotto et al. (17). Not all samples were cultured for pathogen isolation.

${ }^{\mathrm{b}}$ Extracted DNA was amplified using the mitochondrial based Phytophthora genus-specific, P. ramorum, P. nemorosa, and P. pseudosyringae species-specific primer pairs.

c The Phytophthora genus-specific fragment was sequenced and compared to sequence data from known cultures listed in Table 1 to confirm isolate identification.

${ }^{\mathrm{d}} \mathrm{ND}=$ not done.

e P. ilicis-like refers to either P. nemorosa or P. pseudosyringae as noted in Rizzo et al. (35); further classification based on morphology was not done due to the lack of a formal description of the species when the work was done. 
the type cultures of $P$. ramorum and $P$. nemorosa). The fact that the species-specific primers were nested within the Phytophthora genus-specific amplicon also improved the sensitivity of this detection system by nature of a second-round amplification.

The mitochondrial genome is present in multiple copies per cell, thereby improving the sensitivity of the detection system. Using purified pathogen DNA, the detection limit observed with a single round of amplification with the Phytophthora genus-specific primer pair for three isolates of $P$. ramorum was $200 \mathrm{fg}$ of DNA; however, when diluted 1:25 and $1 \mu \mathrm{l}$ used as target DNA for amplification with the $P$. ramorum-specific primer pair, the limit of detection was $2.0 \mathrm{fg}$ for two of the isolates and $20.0 \mathrm{fg}$ for the third. These values compare favorably with detection limits observed with nuclear encoded molecular markers for detection of other Phytophthora spp. Tooley et al. (37) observed detection limits of 1 to $10 \mathrm{pg}$ DNA with $P$. infestans and ITS primers. However, $P$. infestans primers based on families of highly repeated DNA showed 100 times greater sensitivity (10 fg of DNA) compared with ITS based primers (24). Ersek et al. (13) observed detection limits between 20 and 200 pg of DNA for $P$. parasitica and approximately $10 \mathrm{ng}$ of DNA for $P$. citrophthora-specific primers constructed from cloned genomic regions, whereas Schubert et al. (36) reported detection limits of $2 \mathrm{pg}$ for $P$. citricola and $4 \mathrm{pg}$ for $P$. quercina based on primers constructed from cloned random amplified polymorphic DNA bands and $100 \mathrm{pg}$ with $P$. cambivora using primers constructed from the ITS region. Grote et al. (20) developed primer pairs for a nested amplification of $P$. nicotianae and obtained a sensitivity of $2.5 \mathrm{pg}$ following a single round of amplification, but this was increased by 1,000 -fold (to $2.5 \mathrm{fg}$ ) following a second round of amplification using a pair of nested primers. With the $P$. ramorum-specific primers, nested amplification increased sensitivity by a factor of 100 (200.0 fg for a single amplification and $2.0 \mathrm{fg}$ for a nested amplification).

Adding DNA from healthy plant material in an amount equivalent to what would be encountered when processing field samples reduced the sensitivity of $P$. ramorum detection by 100 - to a 1,000-fold depending on the plant species. Addition of DNA from $U$. californica extracted with the Fast Prep DNA extraction kit resulted in an $\approx 100$-fold reduction in sensitivity, whereas DNA from three other plant species reduced the sensitivity by 100 - to 1,000-fold. Seven samples of extracted plant DNA also were obtained that completely inhibited PCR amplification, indicating that the procedure did not remove all inhibitors. Grote et al. (20) also observed that adding DNA from a healthy plant influenced the sensitivity of amplification for $P$. nicotianae-specific primers when using purified pathogen DNA, reducing the limit of detection from $2.5 \mathrm{pg}$ and $2.5 \mathrm{fg}$ for single and nested PCR, respectively, to $60 \mathrm{pg}$ and $60 \mathrm{fg}$, respectively, when the samples were spiked with plant DNA. A similar effect of host DNA on reducing the sensitivity of detection of Phytophthora spp. also was reported by Schubert et al. (36); however, in this example, it appeared that there was a differential response of plant species on amplification. Sensitivity was decreased by a factor of 10 when $100 \mathrm{ng}$ of oak DNA was added to a dilution series of purified pathogen DNA, but no reduction in sensitivity was observed when an equivalent amount of DNA from beech was added. These results highlight the need for optimization of extraction methods for isolating DNA from infected plant material to ensure the full sensitivity of the marker system can be obtained. Clearly, the extraction method used in this current investigation needs to be further optimized to take advantage of the level of sensitivity of the described mitochondrial marker system.

The marker system was developed and validated using an Eppendorf Mastercycler thermal cycler in F. Martin's laboratory. When tested at the same location with an MJ Research PTC-100 using the same amplification parameters, poor or lack of amplification of target sequences was observed. However, reducing the annealing temperatures by $1^{\circ} \mathrm{C}$ provided the same results that were observed with the Eppendorf Mastercycler. Possible reasons for this include different temperature calibration of the heating block as well as different ramping intervals for the two thermal cyclers (the Eppendorf Mastercycler was $3^{\circ} \mathrm{C} / \mathrm{s}$, whereas the MJ Research was $1.4^{\circ} \mathrm{C} / \mathrm{s}$ ). Some of the experiments also were repeated at Ft. Detrick using an Applied Biosystems model 9700 thermal cycler (ramping interval of $2.3^{\circ} \mathrm{C} / \mathrm{s}$ ) with the same results; however, with the Phytophthora genus-specific primer pair, the annealing temperature had to be increased by $1^{\circ} \mathrm{C}$ to reduce background amplification of some plant sequences that were not tested in Salinas. However, by increasing the annealing temperature, several Phytophthora spp. no longer were amplified. These results highlight the need for validation of the marker system and the PCR thermal cycler before it can be used as a diagnostic tool. This would include testing amplification parameters and primer specificity with DNA extracted from healthy plants that will be included in the survey, purified cultures of the pathogen or pathogens in question, and from infected plant tissue where the presence of the pathogen has been confirmed by plating on selective medium. For assays of root and crown samples, it also would be advisable to confirm that the Phytophthora genus-specific primers did not amplify Pythium spp. that may be present.

One potential complication in using this mitochondrial-based marker system for identification of pathogens at the species level is that interspecific hybrids of Phytophthora spp. have been identified $(4,6,11,12,21,29)$. The mitochondrial genome is uniparentally inherited (14); therefore, the hybrids would have a single mitochondrial genotype of one of the parents. Depending on which species functioned as the maternal parent and contributed the mitochondria, the use of a species-specific primer pair may amplify a diagnostic band indicating the presence of a particular species when, in fact, the isolate represented a species hybrid. This was observed in natural hybrids of $P$. nicotianae and $P$. cactorum, all of which had the mitochondrial DNA restriction fragment length polymorphism of $P$. nicotianae (29). In the case of $P$. ramorum, $P$. nemorosa, and $P$. pseudosyringae, data from the nuclear-encoded rDNA ITS region and the mitochondrially encoded coxII gene indicate that these species are phylogenetically distinct and not hybrids (33); therefore, these concerns would not be relevant for these species.

In summary, the PCR-based detection system using the described mitochondrial encoded markers will provide a useful tool for detection of $P$. ramorum and two other species commonly recovered from symptomatic tissue in California and Oregon. One advantage that this marker system has over others that utilize nuclear encoded genes is the emphasis on detecting the presence of Phytophthora spp. in the sample with the first round of amplification rather than focusing on detection of a specific species, thereby improving the diagnostician's ability to determine whether additional pathogens from this genus are present. The system may be used alone or in combination with one of the other PCR-based detection methods now in use for P. ramorum to provide a cytoplasmic marker to complement the nuclear-based markers that have been described $(2,17,42)$. Work currently is in progress on the development of the mitochondrial marker system into a fluorescent real-time PCR assay (15) to increase ease of application and result in more rapid diagnosis of sudden oak death. Given the specificity of the Phytophthora genus-specific primers, the wide range of Phytophthora spp. that they can amplify, and the sequence heterogeneity found in the coxI and II spacer region, these primers should have utility for pathogen detection of other Phytophthora pathosystems as well.

\section{ACKNOWLEDGMENTS}

Mention of trade names or commercial products in this article is solely for the purpose of providing specific information and does not imply recommendation or endorsement by the U.S. Department of Agriculture. 
We thank M. Carras and A. Asche for technical assistance with portions of this study; D. Cooke for providing extracted DNA for 15 of the Phytophthora spp. tested; J. Graham for providing DNA samples from Liriope sp.; and S. Shanker for the DNA sequencing done by the DNA Sequencing Laboratory of the Interdisciplinary Center for Biotechnological Research of the University of Florida, Gainesville. We acknowledge D. Rizzo, E. Hansen, M. Garbelotto, and their labs for the work they are doing on the ecology, biology, and epidemiology of P. pseudosyringae in California.

\section{LITERATURE CITED}

1. Bailey, A. M., Mitchell, D. J., Manjunath, K. L., Nolasco, G., and Niblett, C. L. 2002. Identification to the species level of the plant pathogens Phytophthora and Pythium by using unique sequences of the ITS1 region of ribosomal DNA as capture probes for PCR ELISA. FEMS Microbiol. Letts. 207:153-158.

2. Bilodeau, G., Levesque, C. A., de Cock, A. W. A. M., Kristjansson, G., McDonald, J., and Hamelin, R. C. 2003. Detection and identification of Phytophthora ramorum, causal agent of sudden oak death by molecular beacon. Sudden Oak Death Science Symposium, Monterey, CA.

3. Bonants, P. J. M., Hagenaar-de Weerdt, M., van Gent-Pelzer, M., Lacourt, I., Cooke, D., and Duncan, J. 1997. Detection and identification of Phytophthora fragariae Hickman by the polymerase chain reaction. Eur. J. Plant Pathol. 103:345-355.

4. Bonants, P. J. M., Weerdt, M. H., Man in 't Veld, W. A., and Baayen, R. P. 2000. Molecular characterization of natural hybrids of Phytophthora nicotianae and P. cactorum. Phytopathology 90:867-874.

5. Brasier, C. M., Cooke, D. E., Duncan, J. M., and Hansen, E. M. 2003. Multiple new phenotypic taxa from trees and riparian ecosystems in Phytophthora gonapodyides-P. megasperma ITS clade 6, which tend to be high-temperature tolerant and either inbreeding or sterile. Mycol. Res. 107:277-290.

6. Brasier, C. M., Cooke, D. E. L., and Duncan, J. M. 1999. Origin of a new Phytophthora pathogen through interspecific hybridization. Proc. Natl. Acad. Sci. USA 96:5878-5883.

7. California Department of Food and Agriculture. 2003. Oak Mortality Disease Control. Plant Quarantine Manual 455.1-455.6.

8. Canadian Food Inspection Agency. 2003. Phytosanitary requirements to prevent entry of Phytophthora ramorum associated with sudden oak death into Canada. Directive D-01-01.

9. Caten, C. E., and Jinks, J. L. 1968. Spontaneous variability of single isolates of Phytophthora infestans. I. Cultural variation. Can. J. Bot. 46:329-348.

10. Coyier, D. L., and Roane, M. K. 1986. Compendium of Rhododendron and Azelea Diseases. The American Phytopathological Society, St. Paul, MN.

11. Delcan, J., and Brasier, C. M. 2001. Oospore viability and variation in zoospore and hyphal tip derivatives of the hybrid alder Phytophthora. For. Pathol. 31:65-83.

12. English, J. T., Laday, M., Bakonyi, J., Schoelz, J. E., and Ersek, T. 1999. Phenotypic and molecular characterization of species hybrids derived from induced fusion of zoospores of Phytophthora capsici and Phytophthora nicotianae. Mycol. Res. 103:1003-1008.

13. Ersek, T., Schoelz, J. E., and English, J. T. 1994. PCR amplification of species-specific DNA sequences can distinguish among Phytophthora species. Appl. Environ. Microbiol. 60:2616-2621.

14. Förster, H., and Coffey, M. D. 1990. Mating behavior of Phytophthora parasitica: Evidence for sexual recombination in oospores using DNA restriction fragment length polymorphisms as genetic markers. Exp. Mycol. 14:351-359.

15. Frederick, R. D., Snyder, C. L., Peterson, G. L., and Bonde, M. R. 2002. Polymerase chain reaction assays for the detection and discrimination of the soybean rust pathogens Phakopsora pachyrhizi and P. meibomiae. Phytopathology 92:217-227.

16. Garbelotto, M., Rizzo, D. M., Davidson, J. M., Ivors, K., Maloney, P. E., Huberli, D., Hayden, M., Harnik, T., and Koike, S. T. 2003. An emerging plant pathogen puts California forest ecosystems at risk. Eighth Int. Congr. Plant Pathol. Christchurch, New Zealand.

17. Garbelotto, M., Rizzo, D. M., Hayden, M., Meija-Chang, M., Davidson, J. M., and Tjosvold, S. 2002. Phytophthora ramorum and Sudden Oak Death in California: III. Preliminary studies in pathogen genetics. Pages 765-774 in: Proc. 5th Symp. Calif. Oak Woodlands: Oaks in California's changing landscape. R. Standiford and D. McCreary, eds. U.S. Dep. Agric. For. Serv. Gen. Tech. PSW-GTR-184.

18. Goheen, E. M., Hansen, E. M., Kanaskie, A., McWilliams, M. G., Osterbauer, N., and Sutton, W. 2002. Sudden oak death caused by Phytophthora ramorum in Oregon. Plant Dis. 86:441.

19. Goodwin, S. B., Drenth, A., and Fry, W. E. 1992. Cloning and genetic analysis of two highly polymorphic, moderately repetitive nuclear DNAs from Phytophthora infestans. Curr. Genet. 22:107-115.
20. Grote, D., Olmos, A., Kofoet, A., Tuset, J. J., Bertolini, E., and Cambra, M. 2002. Specific and sensitive detection of Phytophthora nicotianae by simple and nested-PCR. Eur. J. Plant Pathol. 108:197-207.

21. Gu, Y. H., and Ko, W. H. 2000. Segregation following interspecific transfer of isolated nuclei between Phytophthora parasitica and P. capsici. Can. J. Microbiol. 46:410-416.

22. Hansen, E. M., Reeser, P., Davidson, J. M., Garbelotto, M., Ivors, K., Douhan, L., and Rizzo, D. M. 2003. Phytophthora nemorosa, a new species causing cankers and leaf blight of forest trees in California and Oregon, U.S.A. Mycotaxon 88:129-138.

23. Jones, J. 2004. APHIS list of plants regulated and associated with Phytophthora ramorum. Plant Health Progress doi:10,1094/PHP-2003-070701-DG.

24. Judelson, H. S., and Tooley, P. W. 2000. Enhanced polymerase chain reaction methods for detecting and quantifying Phytophthora infestans in plants. Phytopathology 90:1112-1119.

25. Jung, T., Nechwatal, J., Cooke, D. E., Hartmann, G., Blaschke, M., Oswald, W. F., Duncan, J. M., and Delatour, C. 2003. Phytophthora pseudosyringae sp. nov., a new species causing root and collar rot of deciduous tree species in Europe. Mycol. Res. 107:772-789.

26. Kannwischer, M. E., and Mitchell, D. J. 1978. The influence of a fungicide on the epidemiology of black shank of tobacco. Phytopathology 68:1760-1765.

27. Kox, L., de Gruyter, H., Garbelotto, M., van Brouwershaven, I., Admiraal, J., and Baayen, R. P. 2002. Validation of a PCR method for detection and identification of Phytophthora ramorum. Sudden Oak Death Science Symposium, Monterey, CA.

28. Levy, L., and Mavrodieva, V. 2003. Evaluation of the PCR detection and DNA isolation methods for use in the Phytophthora ramorum National Pilot Survey, USDA-APHIS. Sponsored online by APHIS. http://www. ceris.purdue.edu/napis/pests/sod/natplan/nplan02.html.

29. Man in 't Veld, W. A., Veenbaas-Rijks, W. J., Ilieva, E., Cock, A. W. A., Bonants, P. J. M., and Pieters, R. 1998. Natural hybrids of Phytophthora nicotianae and Phytophthora cactorum demonstrated by isozyme analysis and random amplified polymorphic DNA. Phytopathology 88:922-929.

30. Martin, F. N. 1995. Meiotic instability of Pythium sylvaticum as demonstrated by inheritance of nuclear markers and karyotype analysis. Genetics 139:1233-1246.

31. Martin, F. N., and Semer, C. R. 1997. Selection of drug-tolerant strains of Pythium sylvaticum using sublethal enrichment. Phytopathology 87:685692.

32. Martin, F. N., and Tooley, P. W. 2003. Phylogenetic relationships among Phytophthora species inferred from sequence analysis of the mitochondrially-encoded cytochrome oxidase I and II genes. Mycologia 95:269284 .

33. Martin, F. N., and Tooley, P. W. 2003. Phylogenetic relationships of Phytophthora ramorum, P. nemorosa, and P. pseudosyringae, three species recovered from areas in California with sudden oak death. Mycol. Res. 107:1379-1391.

34. Parke, J. L., Linderman, R. G., Osterbaurer, N. K., and Griesbach, J. A. 2004. Detection of Phytophthora ramorum blight in Oregon nurseries and completion of Koch's postulates on Pieris, Rhododendron, Vibernum and Camellia. Plant Dis. 88:87.

35. Rizzo, D. M., Garbelotto, M., Davidson, J. M., Slaughter, G. W., and Koike, S. T. 2002. Phytophthora ramorum as the cause of extensive mortality of Quercus spp. and Lithocarpus densiflorus in California. Plant Dis. 86:205-214.

36. Schubert, R., Bahnweg, G., Nechwatal, J., Jung, T., Cooke, D. E. L., Duncan, J. M., Muller-Starck, G., Langebartels, C., Sandermann, H., Jr., and Osswald, W. 1999. Detection and quantification of Phytophthora species which are associated with root-rot diseases in European deciduous forests by species-specific polymerase chain reaction. Eur. J. For. Pathol. 29:169-188.

37. Tooley, P. W., Bunyard, B. A., Carras, M. M., and Hatziloukas, E. 1997. Development of PCR primers from internal transcribed spacer region 2 for detection of Phytophthora species infecting potatoes. Appl. Environ. Microbiol. 63:1467-1475.

38. USDA-APHIS. 2002. Phytophthora ramorum. Pages 142-148 in: Code of Federal Regulations, Title 7, Pt. 301, Subpart 92.

39. Van der Plaats-Niterink, A. J. 1981. Monograph of the Genus Pythium. Centraal bureau Voor Schimmelcultures, Baarn, the Netherlands.

40. Werres, S., Marwitz, R., Man in 't Veld, W. A., Cock, A. W. A. M., Bonants, P. J. M., Weerdt, M. d., Themann, K., Ilieva, E., and Baayen, R. P. 2001. Phytophthora ramorum sp. nov., a new pathogen on Rhododendron and Viburnum. Mycol. Res. 105:1155-1165.

41. Werres, S., and Zielke, B. 2003. First studies on the pairing of Phytophthora ramorum. Z. Pflanzenkrankh. Pflanzenschutz 110:129-130.

42. Winton, L. M., and Hansen, E. M. 2001. Molecular diagnosis of Phytophthora lateralis in trees, water, and foliage baits using multiplex polymerase chain reaction. For. Pathol. 31:275-283. 